\title{
Controlling Sustainability in Swedish Beef Production: Outcomes for Farmers and the Environment
}

\author{
Klara Fischer $^{1}$ (D) Elin Röös ${ }^{2}$
}

Accepted: 24 April 2018 / Published online: 3 May 2018

(C) The Author(s) 2018

\begin{abstract}
Swedish beef and dairy farmers are currently facing a challenging financial situation. Simultaneously, beef farming contributes significant environmental impacts. To support farmers, actors from the whole value chain are now promoting Swedish beef as particularly 'sustainable'. The paper draws on critical discourse analysis of interviews with and documents from the largest Swedish supermarket chain ICA, Swedish farmer organisations and farmers to study how ICA and farmers articulate sustainability and their responsibility for the same. Articulations are subsequently discussed in the light of actual environmental impacts of beef production and the distribution of power in the beef value chain. The findings suggest that negative environmental impacts and farmers' struggles are largely hidden in the dominant articulation of sustainability. Furthermore, ICA does not use the power it has to steer consumers toward reduced beef consumption. We conclude with suggesting more open deliberation about current levels of beef sales and consumption and about what compromises to make when striving for 'sustainable' beef consumption.
\end{abstract}

Keywords Retail · Food regime $\cdot$ Justice $\cdot$ Agriculture

\section{Introduction}

There is an increased interest in the environmental and social sustainability of food production and consumption, particularly in wealthier parts of Europe (Smith et al. 2010). This interest has

Klara Fischer

klara.fischer@slu.se

Elin Röös

elin.roos@slu.se

1 Department of Urban and Rural Development, Swedish University of Agricultural Sciences, Box 7012, 75007 Uppsala, Sweden

2 Department of Energy and Technology, Swedish University of Agricultural Sciences, Box 7032, 750 07 Uppsala, Sweden 
been taken up by the retail sector, and there are today a wide variety of 'sustainable' choices for consumers to make in European supermarkets (Burch et al. 2013; Chkanikova and Mont 2015; Freidberg 2014; Ponte and Cheyns 2013; Thompson and Lockie 2013). ${ }^{1}$ Promoting 'sustainable' choices can be seen as a way for supermarkets to take some responsibility for the negative side-effects of today's food production and consumption. It is at the same time a way to be associated with the positive concept of 'sustainability' while retaining control over how the concept is operationalised more precisely. This paper presents one example of how sustainability is framed and acted upon by a large supermarket chain, and discusses the impacts of this for farmers and the environment. In the case presented, we describe how the largest Swedish food retailer ICA, and Swedish farmers, on either side of the beef value chain, articulate sustainability and their responsibility for reaching the same. Through a normative lens grounded in 'strong sustainability' we subsequently discuss how dominant articulations and actions affect actual outcomes for sustainable Swedish beef consumption.

Due to methane emissions, beef production is one of the main contributors to climate change in the food system (Gerber et al. 2013). Many are therefore now advocating reduced beef consumption, especially in countries where consumption is high (Bryngelsson et al. 2016; Hedenus et al. 2014; Ripple et al. 2014). In Sweden, per capita beef consumption has increased sharply, from $18.8 \mathrm{~kg}$ in 1995 to $25.9 \mathrm{~kg}$ in 2014 (Sveriges Nötköttsproducenter 2016), which is more than three times the global average of $9 \mathrm{~kg}$ per year (FAO 2015). Approximately half of this amount is imported. At the same time, many Swedish beef and dairy farmers are today facing a challenging financial situation. To support Swedish farmers, Swedish retailers, are now promoting Swedish beef over imported beef, drawing on the concept of 'sustainability' (Sveriges Nötköttsproducenter 2016). However, apart from the general promotion of Swedish beef as more 'sustainable' than imported beef, what this means more precisely remains open to empirical analysis.

At its core the term 'sustainability' builds on the idea that we need to find socially just ways of economic and social development that do not compromise our natural resource base (UNWCED 1987). More precisely what this means is contested (Slätmo et al. 2017). Key contestations have been around ecological limits and how to interpret social justice. Uses of the concept guided by a win-win approach, where the social justice component is toned down, and ecological limits seen as possible to overcome with technology development, have been termed 'weak' (Bond and Morrison-Saunders 2011) or eco-modernist (Baker 2007; Springett 2003). This paper takes its starting point in the contrasting position of 'strong' sustainability. In line with others adopting this approach (Gottschlich and Bellina 2016; Leach et al. 2010; Raworth 2012; UNWCED 1987) we thus acknowledge that there are actual ecological limits that cannot be crossed if sustainability is to be reached (although due to the complexity of ecosystem dynamics these are seldom easy to identify precisely in practice). We also acknowledge that the power to act toward sustainability, as well as the impacts of particular sustainability actions differ across social groups in society and has to be accounted for in practical suggestions for action.

In this paper, we thus ask:

\footnotetext{
${ }^{1}$ Although consumer pressure has been pointed out as an important source for the increasing focus on 'sustainable food' in the retail sector (Smith et al. 2010), we do not include consumers in this study. There are two reasons for this. Firstly, the role of consumers for sustainable food has been dealt with extensively in other studies (e.g. Carolan 2014; Evans 2011; Johnston 2008; Mol 2009; Soper 2004). Secondly, as that literature points out, consumer choices are not developed in isolation but are part of a co-shaping with larger societal values and norms, on which the retail sector has significant influence.
} 
- How is sustainability in beef consumption and production articulated by ICA and Swedish farmers?

- To what extent do these articulations resonate with actual sustainability challenges, and the distribution of power in Swedish beef production and consumption?

We begin by describing the empirical material (2) and the analytical framework (3). After that we outline some dominant discourses on sustainability in European food production (4). Sections 5 and 6 present some facts about the distribution of power in the Swedish beef value chain and environmental challenges with beef consumption. In section 7 , the articulation of sustainability by Sweden's largest supermarket chain ICA is presented, and section 8 presents perspectives of and material impacts for farmers of the current regime. Finally, we discuss these alternative emerging articulations of sustainability in relation to the presented facts on power and environmental impact in the Swedish beef value chain (9). We conclude (10) with a suggestion for more public deliberation on the tensions and trade-offs inherent in 'sustainable' beef production and consumption.

\section{Empirical Material}

The analysis of articulations of sustainability and responsibility for reaching the same at ICA draws on semi-structured interviews with the storeowner and staff responsible for the fresh meat section in two ICA stores, the senior vice-president (SVP) for corporate social responsibility at ICA, and the ICA business area manager of perishable goods (the latter two both working for the company at national level). The stores were selected with the aim of representing one mainstream ICA store without any particular sustainability profile (here referred to as 'mainstream ICA'), and one store with a stated sustainability profile (here referred to as 'eco-friendly ICA'). Interviews were complemented with analysis of relevant websites, ${ }^{2}$ in-store observations, and complementary questions asked by e-mail.

The articulations of sustainability and responsibility by farmers, and farmers' expressions of the material effects of the current Swedish food regime (a food regime being referred to broadly as 'the relations within which food is produced'; McMichael 2009: 281) were analysed drawing on 78 farmer interviews, interviews with the only employee of the Association of Swedish Animal Farmers responsible for membership and finances, and with the expert on sustainable development at the Federation of Swedish Farmers.

The farmer interviews were conducted with visitors to the annual Swedish farm exhibition 'Elmia Livestock and Technology', 21-24 October 2015, by three agronomy students from the Swedish University of Agricultural Sciences. Elmia is the largest regular farm exhibition in Sweden, visited by a wide range of Swedish farmers. Thus we expected the sample to be to some extent representative of Swedish farmers. In order to reach farmers of all kinds, the students were told to approach all visitors, not only those expected to be farmers. Of the 89 interviews conducted, six were excluded as the respondents did not work on farms. Five more

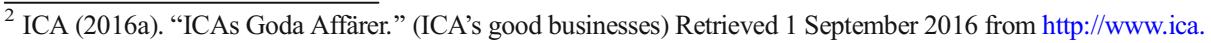
se/ica-tar-ansvar/icas-goda-affarer/

ICA (2016b). "ICA tar ansvar: Kött.” (ICA takes responsibility: Meat) Retrieved 22 September 2016 from http://www.ica.se/ica-tar-ansvar/ravaror/kott/

ICA (2017). "ICAs egna varor." (ICA's own products) Retrieved 23 February 2017 from http://www.ica. se/icas-egna-varor/varumarken/ica-i-love-eco/
} 
were excluded for having marginal farm types (e.g. only forestry or mink farming). The final sample consisted of 78 respondents. Farmers were encouraged to give detailed responses to open-ended questions on the following four issues:

- factors that create challenges in farming.

- factors that could contribute to making it easier to farm.

- negative effects of farming on the surrounding society and the environment.

- positive effects of farming on the surrounding society and the environment.

For each issue, the farmers were encouraged to list at least three aspects. These responses were subsequently categorised inductively into themes and the frequency of themes was analysed with the aid of the Statistical Package for the Social Sciences (SPSS).

All interviews except the 78 farmer-interviews were conducted 9 September and 1 October 2015 by the first author, by telephone or in person. The interviews were recorded and transcribed. Quotes in the text were translated from Swedish to English by the first author. The material were analysed with the following guiding questions:

- How are sustainability and sustainable beef articulated?

- How is the support to Swedish beef farmers articulated?

- How does the interviewee reason around particular actions in relation to this articulation of sustainability?

- What is included and excluded from the articulation of sustainability and sustainable beef production?

- How is responsibility for sustainability and sustainable beef production distributed from consumer to farmer by the respondent?

\section{Analytical Framework}

The analysis of how different articulations of sustainability become dominant over others, is based on Fairclough's critical discourse analysis (CDA) (Chouliaraki and Fairclough 1999; Fairclough 2001, 2003). Fairclough's work provides a range of linguistic tools to aid discourse analysis which help visualise how power is enacted through discourse, e.g. statements of issues as facts or values, general or specific; the degree of certainty with which statements are made, if particular subjects are connected to issues in the form of problem causers or solvers etc.

A brief review of how sustainability has been articulated in European policy, with particular focus on the food sector (section 4), helps positioning the articulations emerging from ICA and farmers in larger relevant discourses (cf. Fairclough 2003).

Fairclough (2003) points out the importance of critical social science that goes beyond discourse, studying actual material impacts of dominant discourses and practices. Thus, to be able to discuss emerging articulations of sustainability in the light of actual material impacts, section 5 describes what is known today about the distribution of power in the beef value chain, and section 6 describes actual environmental impacts of beef production.

An important purpose with visualising power dynamics and inequalities in CDA is to be able to suggest how things could be otherwise (Fairclough 2003). Thus in the discussion (9) we compare articulations of sustainability with the need to stay within some actual ecological limits and pay particular attention to aspects of social justice. 


\section{Sustainability Articulations in European Food Production and Consumption}

Garnett (2014) identifies three main perspectives in society today on how to achieve food system sustainability: efficiency, demand restraint and transformation. While Garnett talks about 'perspectives' we see these as wider societal discourses about food production and consumption that are of value for helping positioning the articulations emerging from ICA and farmers.

The 'efficiency' perspective dominates in society today, according to Garnett (2014). It is supported by most governments, the food industry and retailers. It is characterised by a focus on improving food production rather than changing consumption. It relies heavily on technology development for solving existing tensions between the ideal and actual state of food production sustainability, and it largely black-boxes issues of inequality (Garnett 2014: 12). Although not described as such by Garnett, it is clear that this perspective fits well within an eco-modernist (or 'weak') approach to sustainability (Bond and Morrison-Saunders 2011; Neumayer 2003) which has dominated European policies over the past few decades (Baker 2007; Birch et al. 2010; Couturier and Thaimai 2013; Gottschlich and Bellina 2016; Mol and Spaargaren 2000; Springett 2003). Largely guided by a win-win perspective, it emphasises the possibility of meeting the environmental and social challenges of economic development within the current neoliberal agenda (Mol and Spaargaren 2000).

The latter two perspectives on food system sustainability mentioned by Garnett have less homogeneous trajectories and are significantly more marginal in their political influence (Garnett 2014). Both represent 'strong' sustainability, but in slightly different ways. The demand restraint perspective, traditionally emphasised by environmental conservation organisations, frames humans as dangerous to the environment and focuses on the need to reduce sales and consumption of environmentally damaging foods. Like the efficiency perspective, the focus remains on individuals, and on the environment. It can be pointed out in this context that the environmental dimension of sustainability has been the dominant one in European policies on sustainability since the coining of the concept (Dahl 2012). Lastly, the food system transformation perspective, supported by the organic movement and social justice organisations, is the only of these three where the individual focus is clearly abandoned. This perspective emphasises that responsibility for keeping within the limits of the environment has to be distributed in accordance with the varying means in society to do. It also acknowledges that the systemic aspects of sustainability problems mean both that actual limits are not easily pinned down, and that individual action is insufficient for achieving systemic change. This perspective aligns well with our strong approach to sustainability in this paper.

\section{Concentration in the Swedish Beef Value Chain}

Many Swedish beef farmers today face a challenging situation. Due to increased competition after Sweden's entry into the EU in 1995, the proportion of Swedish meat in total beef purchases declined from over $90 \%$ to approximately 50\% (Sveriges Nötköttsproducenter 2016). As an effect of the increased global competition from the mid-1990s onwards, the 'Swedish Meats' cooperative sold its slaughterhouse business (Scan) to the Finnish HK in 2006, and was transformed into a membership organisation, the Association of Swedish Animal Farmers (Sveriges Djurbönder). Facing increasing financial pressures, many beef and dairy farms have gone out of business and those that remain have grown significantly 
in size. Between 1995 and 2015, the total number of cows (for milk and meat) in Sweden fell from 1.777 to 1.475 million, and the number of farms with cows fell from 42,000 to 17,500 . Simultaneously, the average number of cows per farm increased from 42 to 85 (Statistics Sweden 2015).

In part, the increasingly stressed financial situation experienced by many farmers is connected with the increasing financial and structural power of the retail sector over the past decades (European Commission 2016; OECD 2006; Richards et al. 2013; Sonnino 2013; Thompson and Lockie 2013; Van der Ploeg 2010). Although the concentration of the food chain towards retail is a global trend (European Commission 2016; OECD 2006), Sweden may have the highest concentration of food retailers in Europe (Swedish Government 2016). ICA, the Swedish food and multiple retailer, currently controls over $50 \%$ of the food retail market in Sweden (Brännström 2015). There is now talk of a third 'corporate-environmental food regime' (Friedmann 2005; Smith et al. 2010), of which Sweden clearly is part, where sustainability interests increasingly influence the food system and where food production is largely governed by the retail sector. Following the general trend in the sector (Freidberg 2014), ICA has increased its control over actors upstream. For example, those delivering food to ICA now need certification that they meet one of the standards approved by the Global Food Safety Initiative (GFSI). This is partly a reaction to state withdrawal from food control and globalisation of value chains, but at the same time increased retailer freedom to steer farming has also made it possible for retailers to steer production to be in line with their interests (Freidberg 2014; Thompson and Lockie 2013).

\section{Environmental Impacts of Swedish Beef}

Beef production leads to significantly higher greenhouse gas emissions than the production of alternative protein sources. On average, it emits almost five times more greenhouse gases per $\mathrm{kg}$ than pork, seven times more than chicken and 40 times more than plant-based protein (Clune et al. 2017). Reduction of beef meat can thus be important for reducing the climate impact of our diet.

Cattle (together with other ruminants) can however be raised on feedstuffs that do not compete with human food, such as grass and by-products from the food industry, whereas pigs and poultry require highly digestible (and more frequently imported) feed, often cultivated for that purpose, such as cereals and soy. Some Swedish cattle graze on semi-natural pastures, i.e. unfertilised and untilled land that has been used for grazing for thousands of years. These represent one of the most threatened ecosystems in Sweden, and they rely on grazing to support many endangered plant and animal species (Eide 2014). The open landscapes created by this long-term grazing are also ascribed a high aesthetic and cultural value by the general public in Sweden (Hagerhall 2001).

Nevertheless, many beef producing animals in Sweden are today raised indoors, and fed on substantial amounts of highly digestible feed grown on cropland in order to increase milk yield and growth rate (Hallström et al. 2014), thus not contributing to maintaining these open landscapes. Defining and measuring the accumulated environmental impact of beef production and weighing different aspects against each other, such as climate change impact vs biodiversity loss is clearly not straightforward and involves value judgements. This highlights the need for normative decisions on 'sustainability'. 


\section{Articulating Sustainability at ICA}

ICA strategically positions itself as taking responsibility for sustainable food production, as exemplified in the following quote:

'We're convinced that taking responsibility for both the environment and humans goes hand in hand with financial profit. We work consciously every day to contribute to a sustainable society, for subsequent generations too.' (ICA, 2016a)

When scrutinising how 'sustainability' commitments are translated into concrete words and action, most of ICA's work on 'sustainability' concerns the environment, animal welfare and human (consumer) health aspects. There is a section on the ICA website about 'ethical consumption', but it only relates to the social and economic situation for farmers in developing countries. The strenuous financial situation for Swedish farmers is fairly absent, even when these are seemingly in focus. A section about why ICA promotes Swedish meat states that:

'Swedish animal welfare is among the best in the world. This is one of the reasons why most of ICA's own meat is Swedish. Another reason is that we want to support Swedish farmers so that the Swedish landscape remains open.' (ICA, 2016b)

As exemplified in the quote above, the positive environment and animal welfare aspects of Swedish beef are strategically prioritised in ICA's outward marketing, whereas farmers' social and financial challenges remain largely unmentioned. The abovementioned quotes also show that ICA's way of framing sustainability is clearly eco-modernistic, with no visible tensions between e.g. ecological and financial benefits.

\section{ICA's Articulation of Responsibility for Sustainability}

Individual freedom in the form of consumer choice is at the heart of ICA's business idea and this is rarely compromised, as exemplified in the following statement from the 'mainstream ICA' storeowner:

'Firstly I think that we, I as an ICA retailer, should not decide what you ought to eat. That's not my job, as I see it. But I should give you alternatives and information [...] You can choose between beef sirloin from Sweden or Argentina and you don't need to feel like a criminal if you choose the imported one.' ('mainstream ICA' storeowner)

Choice editing, where ICA actively decides to not sell products, is almost never considered an option for steering consumers towards more sustainable choices and is described as only being used in extreme cases, such as when an item is found to be dangerous. Rather than limiting consumer choice, ICA prefers to direct consumers towards ICA's 'sustainable' options:

'They [the consumers] should not have to be confronted with extremely unsustainable choices, or products that contain hazardous chemicals or what not. But then it is about making the sustainable options visible, but also educating consumers about what sustainability means'. (SVP corporate responsibility, ICA)

Thus while ICA frames itself as a sustainable and responsible company, it does not see as its role to take responsibility through limiting the choices available to consumers. Ultimately it is the individual consumer who has to choose between more and less 'sustainable' options. The responsibility given to consumers is also clearly articulated by ICA's SVP for Corporate 
Responsibility when she describes how ICA envisions contributing to sustainable consumption:

if we just help them [the consumers] to make sustainable choices in a clear and good way, they will make those choices and therefore have the greatest impact. That is our reasoning.' (SVP for Corporate Responsibility, ICA)

The fact that ICA sells products which, according to its own definition of sustainability, are less sustainable, is also portrayed as consumers' fault:

'There are still a large number of people who focus on price. It is price that matters, so they buy Danish pork fillet because it's 30 kroner cheaper per kilo than the Swedish one. They're simply not so engaged in buying Swedish [...]. Those involved in the debate are very engaged consumers, but there's another quite large group of consumers who just say: but I want whipped cream, I don't really care if it's Swedish or imported, I'm going to have that whipped cream.' (SVP for Corporate Responsibility, ICA)

In the same vein, the continued sale of imported meat at ICA is naturalised. Despite ICA's promotion of Swedish beef as more 'sustainable' than imported beef, some of ICA's own processed products contains imported beef and dairy ingredients. This use of non-Swedish products was explained by ICA's SVP for Corporate Responsibility as a result of the current 'shortage' of Swedish beef and milk produced. Another example of naturalising the wish to maintain revenue is the way in which the owner of 'mainstream ICA' talked about a 'need' (rather than a 'desire') for imported meat.

'With regard to beef, we have the problem that Swedish production is insufficient, which makes Swedish meat more expensive, and then consumers are annoyed that it's expensive. So we need the imported meat - in part to cover so that we...-we eat too much meat. And then to keep prices down.' (Storeowner, 'mainstream ICA')

\section{Differing Articulations and Actions for Sustainability at Store Level}

At the level of individual stores, the engagement in promoting 'sustainability' and taking responsibility for promoting 'sustainable' consumption differed greatly. In the 'mainstream ICA' store, the storeowner claimed not to think about sustainability issues at all and stated that he was confident that the control mechanisms by ICA at national level ensured that he would not stock products that are 'bad in any way'. Here the steering by ICA nationally is key to the sustainability work done in-store. In contrast, the 'eco-friendly ICA', guides consumers instore towards making environmentally friendly choices, and selectively promotes products considered better for the environment. In the past this shop even removed Swedish shrimps from its shelves for environmental reasons, despite consumer demand for these. This clearly goes beyond what is considered reasonable in relation to compromising consumer choice at ICA nationally. This store owner even expressed how she sometimes is hindered in her environmental work by ICA at national level. For example, individual retailers are required to stock all the products that ICA puts in the leaflets nationally, and sometimes this had made this store owner have to stock products that she would not like to sell. She however also expressed pride in that she set an example for environmental consciousness, and she felt that she and other likeminded retailers had had some impact in their internal lobbying work when 
now ICA nationally had set out to promote Swedish beef over, in her view less environmentally friendly, imported beef products.

However, what is also clear is that for 'eco-friendly ICA', as for ICA at national level, sustainability remains largely framed as having to do with the impact on the environment. Social and economic aspects are not mentioned. This also characterised the specific reasoning around Swedish meat by the employee responsible for the fresh meat section at the 'ecofriendly ICA'. She emphasised environmental, human health and animal welfare reasons for prioritizing Swedish beef, but social and economic impacts for Swedish farmers remained unmentioned.

\section{Sustainability Articulations and Material Effects for Swedish Farmers}

Reflecting the economic and social challenges in the business, the expert on sustainable development at the Federation of Swedish Farmers described how sustainability for farmers mainly has to do with economic and social dimensions at the moment:

'It is the ones who manage to produce at the lowest costs who have the largest market share. Since the focus on low price - yes that is the focus in all countries, not just in Sweden - it is this, the cheapest shopping basket and the like, price is prioritised over quality, and most of all over environmental aspects.'

This was clearly reflected in the responses from the 78 farmers interviewed, where most of the challenges described related to social and economic dimensions. Eleven categories of farm challenges emerged from the interview responses, of which only two categories (15 out of 144 answers in total) concerned animal welfare and the environment (Table 1).

Instead asking farmers about factors that would contribute to making it easier for them to run their farm resulted in the economy being at the centre again. However, issues about laws, regulations and political decisions were also frequently mentioned (Table 2):

Putting the responses to these two questions together, it is clear that many farmers are very frustrated about financial difficulties, but that beyond the response that the prices are too low and the costs too high, they have difficulty clarifying how the economic challenges could be resolved or what they as farmers can do to resolve them. Examples from the detailed answers about how to deal with the challenges included 'I must minimise my costs' and 'I will just try to survive until things get better', which further exemplifies the reactive stance to the situation adopted by many farmers.

It is also clear that many farmers are frustrated by the politics and regulations surrounding farming. This might partly reflect a feeling of lack of support from the Swedish government, which was also mentioned by both the respondents from the Federation of Swedish Farmers and the Association of Swedish Animal Farmers. They pointed out how the Swedish government has failed to ensure (or not prioritised) that Swedish farmers get the support they can from the EU, and that this lack of government support has made it even more difficult for Swedish farmers to compete than would otherwise have been the case. The respondent from the Federation of Swedish Farmers particularly pointed out how the fact that the Swedish government has decided to keep higher animal welfare standards than minimum requirements in the EU disadvantages Swedish farmers in the competition with farmers in other countries with lower environmental and animal welfare standards. However, the respondents from both the Federation of Swedish Farmers and the Association of Swedish Animal Farmers also 
Table 1 Farmers' responses regarding their challenges in farming

\begin{tabular}{|c|c|c|}
\hline Category & $\begin{array}{l}\text { Responses } \\
\text { (144 in total) }\end{array}$ & Examples of the variety of responses in the category \\
\hline Economy & 61 & $\begin{array}{l}\text { 'The milk price', 'I just have to survive until it gets } \\
\text { better', 'to get the business to go around', } \\
\text { 'produce quality for a low price' }\end{array}$ \\
\hline Regulations and politics & 23 & $\begin{array}{l}\text { 'The politics change all the time', 'all the regulation } \\
\text { and controls', 'paperwork and regulation' }\end{array}$ \\
\hline $\begin{array}{l}\text { Entrepreneurship/ readjusting/adapting } \\
\text { production to changing circumstances }\end{array}$ & 13 & $\begin{array}{l}\text { 'You can never have a bad day', 'to be flexible and } \\
\text { able to read the market, to adapt your production } \\
\text { to changing circumstances' }\end{array}$ \\
\hline Societal/structural preconditions & 10 & $\begin{array}{l}\text { 'Access to certified organic fertiliser', 'too few } \\
\text { slaughter houses to choose between' }\end{array}$ \\
\hline Animal health & 10 & $\begin{array}{l}\text { 'To find good fodder', 'lack of state-employed } \\
\text { veterinarians', 'to keep the animals in good } \\
\text { shape' }\end{array}$ \\
\hline To reach the market & 6 & $\begin{array}{l}\text { 'To reach the local market', 'find a market channel } \\
\text { for niche products' }\end{array}$ \\
\hline Generational renewal & 5 & $\begin{array}{l}\text { 'Age', 'to find someone who wants to take over', } \\
\text { 'high start-up costs' }\end{array}$ \\
\hline Consumer/societal value & 5 & $\begin{array}{l}\text { 'Swedish consumers are spoilt', 'consumers need to } \\
\text { have a better understanding of what it's like to be } \\
\text { a farmer', 'to get people to understand what } \\
\text { Swedish quality is' }\end{array}$ \\
\hline Environmental preconditions & 5 & $\begin{array}{l}\text { 'Problems with wolves and wild boar', 'climate } \\
\text { change' }\end{array}$ \\
\hline Finding staff & 4 & $\begin{array}{l}\text { 'To find staff with the right skills', 'to find temporary } \\
\text { staff' }\end{array}$ \\
\hline Work environment & 2 & 'Reasonable working hours' \\
\hline
\end{tabular}

pointed out that part of the reason for the limited competitiveness of Swedish farmers today has to do with farmer cooperatives not actually being very good at negotiating. Before joining

Table 2 Farmers' responses regarding factors that could contribute to making it easier to run a farm

\begin{tabular}{|c|c|c|}
\hline Category & $\begin{array}{l}\text { Responses } \\
\text { (135 in total) }\end{array}$ & Examples of the variety of responses in the category \\
\hline Economy/profitability & 40 & $\begin{array}{l}\text { 'Higher milk price', 'economy', 'to reduce the costs', } \\
\text { 'to get enough paid' 'better price on beef' }\end{array}$ \\
\hline $\begin{array}{l}\text { Entrepreneurship/ readjusting the } \\
\text { production }\end{array}$ & 40 & $\begin{array}{l}\text { 'Dare to try new things', 'to be able to speak for your } \\
\text { product', 'to stand on several legs' }\end{array}$ \\
\hline $\begin{array}{l}\text { Laws and regulations/ political } \\
\text { decisions }\end{array}$ & 16 & $\begin{array}{l}\text { 'More predictable and stable political steering', 'not } \\
\text { too high tax', 'to have the same regulation as the rest } \\
\text { of the EU' }\end{array}$ \\
\hline $\begin{array}{l}\text { Consumer, societal value and } \\
\text { knowledge about agriculture }\end{array}$ & 8 & $\begin{array}{l}\text { 'To eat what is produced in Sweden', 'to make } \\
\text { consumers choose Swedish products' }\end{array}$ \\
\hline Cooperation with other farmers. & 6 & 'Cooperation with other farmers', 'help each other' \\
\hline Animal health & 6 & 'That the animals are healthy', 'to know your animals' \\
\hline Societal/ structural preconditions & 6 & 'Possibility to rent land', 'access to land', 'the road' \\
\hline To reach the market & 4 & 'To find alternative channels for selling' \\
\hline Work environment & 3 & $\begin{array}{l}\text { 'Time-saving technology', 'to be able to invest in better } \\
\text { working environment' }\end{array}$ \\
\hline Environmental preconditions & 3 & 'To have some luck with the weather' \\
\hline Generational renewal & 2 & 'To get young people engaged in agriculture' \\
\hline Finding staff & 1 & \\
\hline
\end{tabular}


the EU, Swedish farmers were quite protected from competition and both respondents argued that the farmer-led cooperatives did not sufficiently foresee the extent to which they needed to sharpen their negotiation techniques in the face of stiffer competition.

'So we should not blame everything on the retailers either, because it has to do with how they have been allowed to set the price as well' (sustainable development expert at the Federation of Swedish Farmers)

The pressured situation in farming and the reactive position of many farmers has also affected farming organisations. This can be exemplified by the recent liquidation of the Association of Swedish Animal Farmers. The respondent from the Association of Swedish Animal Farmers said that her overall impression was that as many farmers, especially the smaller scale producers, currently are so constrained in terms of time and money they are reluctant to be active paying members in many different organisations. This is also evident in the responses, where only six responses about factors that could make farming easier concerned cooperation with others and/or being part of the farmers' union.

Moving back to the farmer interviews, it often took quite a bit of probing to get the respondents to answer the questions about their farm's negative effects on the surrounding environment and society. It was also clear from the responses that many farmers were quite defensive about their potential negative effects.

The most common answer to the question about the farm's negative effects was that farming has no negative effects, many answers also concerned negative effects for the farm rather than of the farm on its surroundings (Table 3), or were clearly defensive (e.g. 'It is mostly society that thinks that farming is bad for the environment'). Looking in detail into the precise answers behind the categories, the defensiveness in the answers was even clearer: 'If we want to eat animals we must produce them', 'It's impossible for me to be more environmentally friendly if I am to have any financial profit', 'If we're not producing here we will export the environmental problems elsewhere'. It was much easier for the respondents to come up with positive effects (208 responses, Table 4) than negative effects (111 responses, Table 3 ).

As displayed in Table 4, the positive effects listed were however less varied and had much stronger resemblances with the positive environmental effects articulated by ICA, emphasising the role of cattle in preserving biodiversity and open landscapes. The farmers did not highlight positive aspects of the high animal welfare standards in Swedish farming as much as ICA, and farmers brought up some additional positive aspects of their farming, in particular their contribution to employment in the countryside (Table 4).

\section{Discussion}

The key environmental impacts of Swedish beef production are its greenhouse gas emissions (contributing to global warming) and its role in preserving pasture biodiversity (contributing positive environmental and aesthetic outcomes). From a perspective of strong sustainability, and Garnett's (2014) 'food system transformation' perspective, we argue here that overall, Swedish citizens need to reduce their beef consumption significantly to contribute to the global responsibility of mitigating climate change (see Lykkeskov and Gjerris 2017; Nordgren 2012 for a similar argumentation). This can be done without compromising human health and welfare (more likely reduced met consumption even has health benefits: WCRF 2016) and without compromising pasture biodiversity and open landscapes. Röös et al. (2016) estimated 
Table 3 Farmers' responses regarding negative effects of the farm on the surrounding society and environment

Category Responses Comments/ Examples of the variety of responses in the
(111 in total) category

No negative impact or no answer

38

Effects on the climate

16

Nutrient and/or chemical leakage

Other environmental impact

Being an attractive employer

6

5

Societal structural limitations

5

Economics

Own working environment

"It is mostly society that thinks that 3 farming is bad for the environment"

Aesthetics/effects on neighbours Illegible answers
As all farmers were asked these questions in an interview situation, 'no answer' means that the farmer could not come up with any negative impact, not that the questions were missed out. Thus 'no negative impact' and 'no answer' are grouped together.

'Release of methane from the animals', 'carbon dioxide from the tractor'. The category also includes responses about difficulties in finding alternative energy sources, e.g. 'reduce fossil fuels'

'Reduce nitrogen use', 'synthetic fertiliser', 'nutrient leakage', 'the use of chemicals'

'Soil compaction', 'acidification'

'We need more people who want to work in agriculture', 'to be an attractive employer'

This category expresses mainly problems that the farm(er) is facing, rather than problems that the farm is causing. 'I have a big farm which makes it sensitive to changes', 'long transport distances in northern Sweden'

This category included many defensive answers, and expressed mainly problems that the farm(er) is facing rather than problems that the farm is causing. 'It is associated with the economy, we need a lot of animals to make a decent profit', 'you cannot be environmentally friendly and make a profit'

This category expressed mainly problems that the farm(er) is facing rather than problems that the farm is causing. 'I work too much', 'the psycho-social environment'

There were three responses that were very similar and that can be represented by quoting one of those responses.

that Swedish consumption of beef meat can be reduced with more than half without threatening the pasture biodiversity if the beef meat consumed is sourced from production systems using semi-natural pastures.

Retailers and farmers have vastly different possibilities to influence beef consumption. Beef farmers produce precisely beef and commonly no alternative to beef, and they are often positioned far away from consumers in the supply chain. Retailers on the other hand, meet consumers directly, stock many alternatives to beef meat and can heavily influence consumer choice by how food is exposed, marketed and priced etc. (cf. Carolan 2014 and footnote 1). However our discourse analysis shows that ICA's articulation and action on sustainability both hides the company's power, and is vastly insufficient for reaching goals of strong sustainability in beef consumption. On paper, ICA takes some responsibility for sustainable beef production through their promotion of Swedish beef in general. This study however shows that overall ICA as a company is not willing to do this to the extent that they also discourage purchasing of imported meat. 
Table 4 Farmers' responses regarding positive effects of the farm on the surrounding society and environment

\begin{tabular}{|c|c|c|}
\hline Category & $\begin{array}{l}\text { Responses }(208 \\
\text { in total) }\end{array}$ & Examples of the variety of responses in the category \\
\hline General benefits of production & 58 & $\begin{array}{l}\text { 'Good environment', 'quite sustainable', 'I make productive } \\
\text { use of our natural resources', 'it is better for the climate } \\
\text { when the food is produced in Sweden' }\end{array}$ \\
\hline Landscape/biodiversity & 50 & $\begin{array}{l}\text { 'Open landscapes', 'biodiversity', 'conserving natural } \\
\text { pastures' }\end{array}$ \\
\hline Employment & 27 & $\begin{array}{l}\text { Comments about providing employment in general and } \\
\text { employment in rural areas in particular }\end{array}$ \\
\hline $\begin{array}{l}\text { General environmental } \\
\text { benefits }\end{array}$ & 18 & $\begin{array}{l}\text { 'It is good for the environment', 'the production is quite } \\
\text { sustainable' }\end{array}$ \\
\hline Locally produced food & 13 & 'Locally produced food', 'short transport distances' \\
\hline A living countryside & 12 & $\begin{array}{l}\text { Includes comments about providing opportunities for } \\
\text { tourism }\end{array}$ \\
\hline Food security/ self sufficiency & 9 & $\begin{array}{l}\text { 'I produce products that we as humans need to live', 'it's } \\
\text { important for security reasons that we have food } \\
\text { production in Sweden' }\end{array}$ \\
\hline $\begin{array}{l}\text { Technology and knowledge } \\
\text { development }\end{array}$ & 8 & $\begin{array}{l}\text { 'I contribute with knowledge about farming', 'I develop new } \\
\text { technology' }\end{array}$ \\
\hline $\begin{array}{l}\text { Good/ethical animal } \\
\text { husbandry }\end{array}$ & 8 & $\begin{array}{l}\text { 'Low use of antibiotics', 'low use of medicines', 'high } \\
\text { animal welfare' }\end{array}$ \\
\hline Illegible answer & 5 & \\
\hline
\end{tabular}

The dominant way of articulating sustainability at ICA has strong ecomodernist roots, where actual ecological limits, trade-offs between social- ecological end economic dimensions and between different actors' interests are largely hidden. It bears a strong similarity with what Garnett (2014) terms the 'efficiency' perspective of sustainable food security, which is widely embraced by both food retail and governments today, and where trade-offs are hidden or seen as resolvable through technological progress. ICA's reluctance to steer consumers also aligns with this view, as well as with the wider trend in the sector of increasingly controlling farming rather than consumption (Freidberg 2014; Richards et al. 2013; Thompson and Lockie 2013).

In line with ICA's reluctance to steer consumers, research has shown that despite increased retailer interest in marketing 'sustainable' products and stocking sustainable choices, many retailers are reluctant to exclude 'unsustainable' products, and only to a limited extent guide their customers towards 'sustainable' products, arguing that people should be free to choose what they purchase (Chkanikova and Mont 2015; Jones et al. 2008; Tjärnemo and Södahl 2015). To some extent this can be seen as an intertextual iteration of larger discourses in our neoliberal society about individual freedom (Harvey 1996). It must however be noted that this apparent reluctance to steer consumers toward sustainability goes against how the retail industry generally aims to steer consumer behaviour, and also in the present case is a way for ICA to ensure that it does not compromise sales, while still making sure to be associated with the positive connotations of 'sustainability'.

It is at the same time clear from the findings that it takes significant commitment and potential economic loss for individual ICA retailers to take more substantial steps toward steering consumers for sustainability than is promoted by ICA at national level. In the wider political economic environment of state withdrawal from food control (Freidberg 2014; Smith et al. 2010), individual retailers committed to sustainability are in effect punished by the effects of the free market. In this context it can also be questioned to what extent private business, such as ICA, can be expected to go much further than they do today to steer consumers toward 
sustainability.. Indeed much research in the field now suggests that increased state intervention is needed to steer food production and consumption more significantly toward sustainability (Lykkeskov and Gjerris 2017; Nordgren 2012).

Despite the significant climate impact of beef production the farmers in our study only acknowledged their environmental impact to a limited extent. This resonates with research on the topic which indicates that many Swedish farmers downplay the role of anthropogenic causes of climate change and do not see a great need to implement climate change mitigation measures (Asplund 2016). We would like to suggest however, that the limited focus on the negative climate impact of beef amongst farmers seen in this study might not necessarily mean that farmers do not acknowledge these negative effects, but rather that they see themselves as being unfairly cast as the actors who are mainly responsible for the environmental impacts of our common food choices, and unfairly burdened with the economic cost of reducing environmental impact. For example, keeping animals on semi-natural pastures is more labour intensive and, depending on the payments for grazing (in the form of EU subsidies) that the farm is entitled to, it can also be less profitable than raising calves as bulls indoors (Hessle and Kumm 2011).

Overall, the findings indicate that Swedish beef farmers today feel pressured financially and see limited possibilities for changing their own situation. Moreover, they feel that they get limited appreciation from the wider society for their work, as reflected e.g. in the statements "Swedish consumers are spoiled" (Table 1) and "It is mostly society that thinks that farming is bad for the environment" (Table 3). However, it is notable that the Swedish farmers only to a very limited extent expressed frustration with the effects of the increasing power concentration towards retailers. Viewed historically, the very limited control that farmers have over the food regime today is exceptional (Smith et al. 2010). Thus, farmers could be expected to express significant frustration with this, as seen in many other parts of the world (Edelman 2005). Thompson and Lockie (2013) for example describe how Australian farmers refer to themselves as 'serfs' or 'peasants' in a direct criticism to being increasingly steered by powerful supermarkets. The Swedish farmers expressed much more frustration with EU bureaucracy and a lack of support from the Swedish government for farming than with the negative effects for them of the concentration in retail. One way of interpreting this is that farmers normalise the effects of neoliberalism, despite it working against them (Akram et al. 2015). A slightly different interpretation is that this is a conscious criticism of the current order by farmers who do not see a possibility of changing the retail sector, but feel that they might be able to influence Swedish government policy. It is worth noting that the neoliberal restructuring of the food system, although displaying some general global trends, is context-specific. Swedish farming organisations often point out that the Finnish government has been significantly more proactive in securing Finnish farmers' interests within the EU (SVT NYheter 2012), while Richards et al. (2013) report that the cooperative system in Norway is continuing to protect and support farmers in their negotiations with major food retailers.

In the light of farmers' limited influence on the corporate food regime it is notable that very few farmers acknowledged the possibility of organising themselves for increasing their influence. Only six responses of a total of 135 about factors that could make farming easier (Table 2) concerned cooperation with others and/or being part of the farmers' union. This might in part be interpreted as a result of the dominance of neoliberal ideology, which frames the ideal farmer as an independent entrepreneur (cf. Stock et al. 2014). It can also, as mentioned by the respondent from the Swedish Animal Farmers, be seen as an outcome of a material reality where farmers pressured for time and money feel the need to prioritise the own farm work over e.g. political- or farmers' union engagement. 


\section{Conclusions}

In summary, ICA's dominant articulation of sustainability in Swedish beef production is strongly ecomodernist and facilitated by the wider neoliberal food regime. It however blocks wider public acknowledgement of actual sustainability challenges for three reasons:

1) it depoliticises food production and consumption by giving the impression that sustainability can be reached through consumers simply choosing the more sustainable of available options, without a need for systemic change,

2) it hides the fact that it is the retailers and the state rather than the farmers or consumers who have the power to act for greater sustainability

3) it avoids talking about the need to actually reduce beef consumption in Sweden,

From a perspective of strong sustainability, beef consumption can and must be reduced for environmental reasons, but all other things similar, this would be to the detriment of Swedish beef farmers. Thus, from a social justice perspective, beef farmers would then have to be supported to enable a transition away from beef farming, or continue at a scale and intensity that is compatible with strong commitments to sustainability. It is clear that reaching strong sustainability in beef production and consumption would require significant restructuring of the food system. Therefore we suggest, like much research in this vein (Lykkeskov and Gjerris 2017; Nordgren 2012) that further state intervention is needed to steer the retail sector, and that we need simultaneously to open this issue up for public deliberation (Leach et al. 2010; Carolan 2014), where citizens rather than consumers are given access to the facts of the matter and can deliberate within the democratic system on different pathways to sustainable beef.

Acknowledgements The research for this paper was funded by the cross-disciplinary research platform Future Agriculture, at the Swedish University of Agricultural Sciences. We want to thank the respondents for taking time to talk to us and our students. We would also like to thank the students Thea Kristensson, Sara Sjöqvist and Gustav Broms for conducting interviews with farmers at the Elmia Exhibition, and for taking time to give us detailed responses on their experiences. Thank you to Mikaela Nilsson for helping us input interview responses in SPSS and to Mikaela Nilsson and Elin Slätmo for being supportive in the discussion about the categorisation of responses.

Open Access This article is distributed under the terms of the Creative Commons Attribution 4.0 International License (http://creativecommons.org/licenses/by/4.0/), which permits unrestricted use, distribution, and reproduction in any medium, provided you give appropriate credit to the original author(s) and the source, provide a link to the Creative Commons license, and indicate if changes were made.

\section{References}

Akram, S., Emerson, G. and Marsh, D. 2015. (Re) Conceptualising the third face of power: insights from Bourdieu and Foucault. Journal of Political Power 8: 345-362.

Asplund, T. 2016. Natural versus anthropogenic climate change: Swedish farmers' joint construction of climate perceptions. Public Understanding of Science 25 (5): 560-575.

Baker, S. 2007. Sustainable development as symbolic commitment: Declaratory politics and the seductive appeal of ecological modernisation in the European Union. Environmental Politics 16 (2): 297-317.

Birch, K., L. Levidow, and T. Papaioannou. 2010. Sustainable capital? The neoliberalization of nature and knowledge in the European "knowledge-based bio-economy". Sustainability 2 (9): 2898-2918. 
Bond, A.J., and A. Morrison-Saunders. 2011. Re-evaluating sustainability assessment: Aligning the vision and the practice. Environmental Impact Assessment Review 31 (1): 1-7.

Brännström, S. 2015. Få aktörer har makten över maten. Svenska Dagbladet http://www.svd.se/fa-matkedjor-attvalja-pa/om/makten-over-maten. Accessed 27 June 2015.

Bryngelsson, D., S. Wirsenius, F. Hedenus, and U. Sonesson. 2016. How can the EU climate targets be met? A combined analysis of technological and demand-side changes in food and agriculture. Food Policy 59: 152-164.

Burch, D., J. Dixon, and G. Lawrence. 2013. Introduction to symposium on the changing role of supermarkets in global supply chains: From seedling to supermarket: Agri-food supply chains in transition. Agriculture and Human Values 30 (2): 215-224.

Carolan, M. 2014. Future food 'needs': From consumer to citizen choice. Sociologia Ruralis 54 (1): 98-100.

Chkanikova, O., and O. Mont. 2015. Corporate supply chain responsibility: Drivers and barriers for sustainable food retailing. Corporate Social Responsibility and Environmental Management 22 (2): 65-82.

Chouliaraki, L., and N. Fairclough. 1999. Discourse in late modernity: Rethinking critical discourse analysis. Edinburgh: Edinburgh University Press.

Clune, S., E. Crossin, and K. Verghese. 2017. Systematic review of greenhouse gas emissions for different fresh food categories. Journal of Cleaner Production 140: 766-783.

Couturier, A. and K. Thaimai. 2013. Eating the fruit of the poisonous tree ecological modernisation and sustainable consumption in the EU. Working paper no. 20/2013. Berlin: Institute for International Political Economy.

Dahl, A.L. 2012. Achievements and gaps in indicators for sustainability. Ecological Indicators 17: 14-19.

Edelman, M. 2005. Bringing the moral economy back in... To the study of 21 st-century transnational peasant movements. American Anthropologist 107 (3): 331-345.

Eide, W. 2014. Arter och naturtyper i habitatdirektivet - bevarandestatus i Sverige 2013. (Species and habitats in the habitats directive - conservation status in Sweden 2013.) Uppsala: The Swedish species information Centre.

European Commission. 2016. Report from the commission to the European parliament and the council on unfair business-to-business trading practices in the food supply chain. Brussels: European Commission.

Evans, D. 2011. Consuming conventions: sustainable consumption, ecological citizenship and the worlds of worth. Journal of Rural Studies 27 (2): 109-115.

Fairclough, N. 2001. Language and power. Harlow: Pearson Education Limited.

Fairclough, N. 2003. Analysing discourse: Textual analysis for social research. Oxon and New York: Routledge.

FAO. (2015). FAOSTAT. The Food and Agriculture Organization, Rome. Available from http:/faostat.fao. org/default.aspx

Freidberg, S. 2014. Footprint technopolitics. Geoforum 55: 178-189.

Friedmann, H. 2005. From colonialism to green capitalism: Social movements and emergence of food regimes. In New directions in the sociology of global development. Research in rural sociology and development, ed. F. Buttel and P. McMichael, 227-264. Oxford: Elsevier.

Garnett, T. 2014. Three perspectives on sustainable food security: Efficiency, demand restraint, food system transformation. What role for life cycle assessment? Journal of Cleaner Production 73: 10-18.

Gerber, P.J., H. Steinfeld, B. Henderson, A. Mottet, C. Opio, J. Dijkman, A. Falcucci, and G. Tempio. 2013. Tackling climate change through livestock - a global assessment of emissions and mitigation opportunities. Rome: Food and Agriculture Organization of the United Nations.

Gottschlich, D., and L. Bellina. 2016. Environmental justice and care: Critical emancipatory contributions to sustainability discourse. Agriculture and Human Values 34 (4): 1-13.

Hagerhall, C. 2001. Consensus in landscape preference judgements. Journal of Environmental Psychology 21 (1): 83-92.

Hallström, E., E. Röös and P. Börjesson. 2014. Sustainable meat consumption: A quantitative analysis of nutritional intake, greenhouse gas emissions and land use from a Swedish perspective. Food Policy 47(0): 81-90.

Harvey, D. 1996. Justice, nature and the geography of difference. Oxford: Blackwell Publishing.

Hedenus, F., S. Wirsenius, and D.A. Johansson. 2014. The importance of reduced meat and dairy consumption for meeting stringent climate change targets. Climatic Change 124 (1-2): 79-91.

Hessle, A., and K.I. Kumm. 2011. Use of beef steers for profitable management of biologically valuable seminatural pastures in Sweden. Journal for Nature Conservation 19 (3): 131-136.

ICA (2016a). “tar ansvar: Kött.” (ICA takes responsibility: Meat) Retrieved 22 September 2016 from http://www. ica.se/ica-tar-ansvar/ravaror/kott/.

ICA (2016b). "ICAs Goda Affärer.” (ICA’s good businesses) Retrieved 1 September 2016 from http://www.ica. se/ica-tar-ansvar/icas-goda-affarer/.

Johnston, J. 2008. The citizen-consumer hybrid: ideological tensions and the case of Whole Foods Market. Theory and Society 37 (3): 229-270.

Jones, P., D. Comfort, and D. Hillier. 2008. Corporate social responsibility and marketing communications within stores: A case study of U.K. Food retailers. Journal of Food Products Marketing 14 (4): 109-119. 
Leach, M., I. Scoones, and A. Stirling, eds. 2010. Dynamic sustainabilities: Technology, environment, social justice. London and Washington DC: Earthscan.

Lykkeskov, A., and M. Gjerris. 2017. The moral justification behind a climate tax on beef in Denmark. Food Ethics. 1 (2): 181-191.

McMichael, P. 2009. A Food Regime Analysis of the 'World Food Crisis'. Agriculture and Human Values. 26, 281-295.

Mol, A. 2009. Good taste: The embodied normativity of the consumer-citizen. Journal of Cultural Economy 2 (3): 269-283.

Mol, A.P., and G. Spaargaren. 2000. Ecological modernisation theory in debate: A review. Environmental Politics. 9 (1): 17-49.

Neumayer, E. 2003. Weak versus strong sustainability: Exploring the limits of two opposing paradigms. Cheltenham: Edward Elgar Publishing.

Nordgren, A. 2012. Ethical Issues in Mitigation of Climate Change: The Option of Reduced Meat Production and Consumption. Journal of Agricultural and Environmental Ethics 25 (4): 563-584.

OECD. 2006. Supermarkets and the meat supply chain: The economic impact of food retail on farmers, processors and consumers. Paris: OECD Publishing.

Ponte, S., and E. Cheyns. 2013. Voluntary standards, expert knowledge and the governance of sustainability networks. Global Networks 13 (4): 459-477.

Raworth, K. 2012. A safe and just space for humanity: Can we live within the doughnut? Oxfam Discussion Papers. Oxford: Oxfam.

Richards, C., H. Bjørkhaug, G. Lawrence, and E. Hickman. 2013. Retailer-driven agricultural restructuringAustralia, the UK and Norway in comparison. Agriculture and Human Values 30 (2): 235-245.

Ripple, W.J., P. Smith, H. Haberl, S.A. Montzka, C. McAlpine, and D.H. Boucher. 2014. Ruminants, climate change and climate policy. Nature Climate Change 4 (1): 2-5.

Röös, E., Patel, M., Spångberg, J., Carlsson, G. \& Rydhmer, L. 2016. Limiting livestock production to pasture and by-products in a search for sustainable diets. Food Policy, 58, 1-13.

Slätmo, E., K. Fischer, and E. Röös. 2017. The framing of sustainability in sustainability assessment frameworks for agriculture. Sociologia Ruralis 57 (3): 378-395.

Smith, K., G. Lawrence, and C. Richards. 2010. Supermarkets' governance of the agri-food supply chain: Is the 'corporate-environmental 'food regime evident in Australia? International Journal of Sociology of Agriculture and Food. 17 (2): 140-161.

Sonnino, R. 2013. Local foodscapes: Place and power in the agri-food system. Acta Agriculturae Scandinavica. Section B-Soil \& Plant Science 63 (sup1): 2-7.

Soper, K. 2004. Rethinking the "good life": The consumer as citizen. Capitalism Nature Socialism 15 (3): 111-116.

Springett, D. 2003. Business conceptions of sustainable development: A perspective from critical theory. Business Strategy and the Environment 12 (2): 71.

Statistics Sweden. 2015. Statistiska meddelanden: Husdjur i juni 2015/Livestock in June 2015, Report number: Jo 20 sm 1502. Stockholm: Statistics Sweden.

Stock, P.V., J. Forney, S.B. Emery, and H. Wittman. 2014. Neoliberal natures on the farm: Farmer autonomy and cooperation in comparative perspective. Journal of Rural Studies 36: 411-422.

Sveriges Nötköttsproducenter. 2016. Handlingsplan nöt: För att öka svensk nötköttsproduktion. Vaggeryd: Sveriges Nötköttsproducenter (the Association of Swedish Beef Producers).

SVT NYheter. 2012. "Finska bönder făr bättre bidrag än svenska" (Finish farmers recieve more financial support than Swedish) [on-line] https://www.svt.se/nyheter/lokalt/vasterbotten/finska-bonder-far-storrebidrag-ansvenska (publisjed 2012-12-11, accessed 2018-04-30).

Swedish Government. 2016. Regeringens proposition 2016/17:104 en livsmedelsstrategi för Sverige - fler jobb och hållbar tillväxt $i$ hela landet. Stockholm: Swedish Government.

Thompson, L.J., and S. Lockie. 2013. Private standards, grower networks, and power in a food supply system. Agriculture and Human Values 30 (3): 379-388.

Tjärnemo, H., and L. Södahl. 2015. Swedish food retailers promoting climate smarter food choices-trapped between visions and reality? Journal of Retailing and Consumer Services 24: 130-139.

UNWCED. 1987. Our common future. Oxford: Oxford University Press.

Van der Ploeg, J.D. 2010. The peasantries of the twenty-first century: The commoditisation debate revisited. The Journal of Peasant Studies. 37 (1): 1-30.

WCRF. 2016. Cancer prevention and survival: Summary of global evidence on diet, weight, physical activity and what increases or decreases your risk of cancer. London: World Cancer Research Fund. 